This is a pre-print of an article published in International Entrepreneurship and Management Journal. The final authenticated version is available online at:

Samara, G.; Berbegal-Mirabent, J. (2018). Independent directors and family firm performance: does one size fit all? International Entrepreneurship and Management Journal, 14(1): 149-172. https://doi.org/10.1007/s11365-017-0455-6

\title{
Independent Directors and Family Firm Performance: Does One Size Fit All?
}

\section{Abstract}

How will independent directors presence affect family business performance? This question is still theoretically debated and empirically inconclusive. Because family businesses are a group of heterogeneous companies, the purpose of this paper is to empirically explore how the combination of different family business governance structures can jointly shape the effect of independent directors on family business performance in an understudied Collectivist cultural setting. Using Qualitative Comparative Analysis (QCA) on a sample of 74 Lebanese family firms this study finds that, depending on the family firm governance structure, the presence of independent directors on the board can lead to either positive or negative firm performance. Theoretical and practical implications are discussed.

Keywords: Collectivism; Corporate Governance; Family Business Heterogeneity; Independent Directors; Performance.

\section{Introduction}

Holdal Group, a Lebanese 100\% family owned firm, has been featured in 2014 for the second consecutive year as one of the top 100 companies in the Arab world (Forbes Middle East, 2014). One of the distinctive features of this company is that the chairs of its board of directors 
are exclusively held by family members. This contradicts the common prescription in corporate governance codes around the world that suggests that the presence of independent directors on the board is necessary to achieve firm survivability and success. In fact, in the distinctive context of family businesses, the relationship between the presence of independent directors on the board and firm performance is theoretically debated yet empirically inconclusive. Theoretically, research adopts agency (Jensen \& Meckling, 1976) and stewardship theories (Davis, Shoorman, \& Donaldson, 1997) as separate lens to determine the effect of independent directors on firm performance (Madison, Holt, Kellermanns, \& Ranft, 2016). Empirically, positive (e.g. Anderson \& Reeb, 2004; Arosa, Iturralde, \& Maseda, 2010; Kuo \& Hung, 2012), negative (e.g. Agrawal \& Knoeber, 1996; Garcia-Ramos \& Garcia-Ollala, 2011), and no effect (e.g. Cuadrado-Ballesteros et al., 2015; Dalton, Daily, \& Allstrand, 1998; Gnan, Montemerlo, \& Huse, 2015) of independent directors presence is associated to family business performance.

The existence of competing arguments and inconclusive findings indicates that the presence of independent directors on the family business board may sometimes, but not always contribute to family business performance. Hence, because family businesses are a group of heterogeneous companies having different governance structures (Chrisman, Sharma, Steier, and Chua, 2013; Nordqvist, Sharma, and Chirico, 2014) and because the Collectivist cultural setting is an important institutional setting that affects the success or failure of governance mechanisms in family firms (Pagliarussi and Rapozo, 2011; Sharma, 2004; Sharma and Manikutty, 2005) but has been largely disregarded in extant literature, the aim of this paper is to explore the following question: in a Collectivist culture, how do different family business governance contingencies shape the effect of independent directors on family business performance? 
In doing so, this study contributes to the corporate governance literature in family firms and provides practical contributions to family business owners, advisors, and policy makers. Theoretically, the study shows that agency and stewardship theories can mutually serve their purpose in explaining family business behavior (Madison et al., 2016) and reconciles previous competing arguments and conflicting results found in the literature. Moreover, by exploring Lebanese family businesses, this paper responds to calls from Anderson and Reeb (2004), Evert, Martin, Mcleod, and Payne (2016), and Villalonga and Amit (2006) to explore new geographical cultural settings to truly understand strategic decision making in family firms. The study also responds to calls from Chrisman et al. (2013) and Nordqvist et al. (2014) to start using a configuration approach to unfold the complex systems of interdependencies that allows for a better explanation of family business behavior. Particularly we find that, depending on the combination of several governance contingencies, the presence of independent directors on the family firm board can either be an asset or a liability. For practitioners, this paper offers several governance recipes that can assist Collectivist family business owners and advisors to decide when the appointment of independent directors should be encouraged or discouraged to achieve better firm performance.

Using QCA, this paper addresses the above mentioned question by exploring the effect of independent directors on the performance of 74 Lebanese companies across different combinations of governance contingencies. QCA is an increasingly popular method in management (Huarng, 2015) and in family business research (e.g. Garcia-Castro and Aguilera, 2014; Kraus, Mensching, Calabrò, Cheng, \& Filser, 2016) that allows to investigate heterogeneous combinations of causal conditions that lead to a certain outcome (Ragin, 2008). We believe that through the recognition of complexity theory, this study contributes to the 
existing literature by offering an interesting case for the comparison of results employing the simplistic narrative of linear relations among variables against results employing a more nuanced analytical technique that allows for the identification of counter-intuitive and multi-dimensional causal recipes.

The remainder of the paper is structured as follows. In the next section, we clearly differentiate independent directors from other board members. Next, we review relevant research in agency and stewardship theories to provide an explanation of the different theorized roles of independent directors on the board of family firms. Moving forward, we argue how the Collectivist cultural setting shapes the attitudes of family members inside the firm. Then, we discuss how different governance contingencies shape the effect of independent directors on family business performance. The subsequent sections present and explain our data and results. Lastly, we elaborate on the theoretical contributions, and conclude withthe practical implications.

\section{Board of Directors: Insiders, Affiliates, and Independents}

The members of the board of directors are classified as insiders or outsiders. Insiders include firm employees, retired employees and/or family members. Outside directors respond to either affiliates or independent directors (Jensen \& Meckling, 1976; Voordeckers, Van Gils, \& Van den Heuvel, 2007; Zahra \& Pearce, 1989). Affiliates are directors that have potential or existing personal relationships with the family and/or the firm (e.g. Anderson \& Reeb, 2004; Jones, Makri, \& Gomez-Mejia, 2008). Examples of affiliates include lawyers, investment bankers, financiers, and consultants (e.g. Anderson \&Reeb, 2004; Arosa et al., 2010). Independent directors are outsiders that have no social ties neither with the company nor with the family. Instead, their sole relationship with the business begins with their directorship. The main difference between affiliates and independent directors is that affiliates, due to their long term 
business relationship, are able to forge strong social relationships with the top management team. However, independent directors usually serve for a shorter period of time and have less opportunity to forge social ties with the management team or the family. While affiliates can play an advisory role without affecting the perceived control of the family over the business, independent directors can be perceived as a threat to the family's control and decision making ability (Anderson \& Reeb, 2004; Jones et al., 2008; Westphal, 1999). The following section presents agency and stewardship theories to discuss the effect of the presence of independent directors on family business performance.

\section{Theoretical Framework: Agency and Stewardship Theories}

\subsection{Agency Theory}

Agency theory suggests that principals (i.e. owners) delegate some agents (i.e. managers) to run the company on their behalf. Agency theory predicts that a conflict of interest arises when opportunistic managers seek to achieve their own self-interest on the detriment of the interests of less informed shareholders (Jensen \& Meckling, 1976). As a remedy for this conflict of interest, Fama and Jensen (1983) suggest that monitoring by independent directors can be one of the effective measures to control opportunistic behavior of agents and to re-align interests of owners and managers.

Yet, whether family firms need independent directors to monitor the management team is still debatable. In this regard research offers two competing stances. The first stance suggests that family involvement in ownership and management creates an automatic alignment of interest between shareholders and family managers that mitigates information asymmetries and reduces agency costs (Chrisman, Chua, \& Litz, 2004; Herrero, 2011; Jensen \& Meckling, 1976; Zahra \& Santon, 1988). In addition, motivated by the protection of the family's financial wealth, family 
managers are in a good position and have strong incentives to monitor other non-family employees (Anderson, Duru, \& Reeb, 2009). Given the aforementioned considerations the presence of independent directors has been considered as an additional unnecessary cost when the business is family owned (Fama \& Jensen, 1983).

Contrarily, the second stance stretches the theoretical boundaries of agency theory suggesting that non-traditional agency problems such as asymmetric altruism (Chua, Chrisman, \& Bergiel, 2009; Schulze, Lubatkin, Dino, \& Buchholtz, 2001) and family entrenchment (e.g. Villalonga \& Amit, 2006) result from opportunistic attitudes of family managers. Asymmetric altruism creates a moral hazard agency problem where family controlling owners are excessively generous towards their kin and hold back from monitoring unqualified opportunistic family members (Chua et al., 2009; Schulze et al., 2001). Also, entrenchment creates an adverse selection problem where family controlling owners employ family members regardless of their qualifications resulting in the presence of an unqualified management team and in the loss of managerial talent (e.g. Chrisman et al., 2014; Schulze et al., 2001). These problems are identified as a type one agency problem.

A principal-principal conflict of interest is identified as a type two agency problem. Due to the dominant family shareholders desire for income and wealth preservation within the family, family shareholders can become more risk averse and can have incentives to engage in non-profit maximizing objectives that only serve family interests (Anderson \& Reeb, 2004; Le BretonMiller \& Miller, 2009; Pagliarussi \& Rapozo, 2011). This conflict of interest also occurs in the presence of a multi-family firm where different extended family groups own the business (Pagliarussi \& Rapozo, 2011). For example, family shareholders are prone to extract private rents through special dividends, excessive compensation schemes, and through diverting 
company assets for private use (Anderson \& Reeb, 2004). Recent evidence suggests that this principal-principal conflict of interest is especially likely when firm performance deteriorates, when the CEO is a family member, and when the founder is no longer involved in the business (Martin, Gomez-Mejia, Makri, \& Berrone, 2016). Hence, the presence of independent directors on the family firm board becomes an essential control mechanism to reduce agency costs and to achieve better firm performance (e.g. Anderson \& Reeb, 2004; Bammens, Voordeckers, \& Van Gils, 2011)

\subsection{Stewardship Theory}

Alternatively, stewardship theory holds different assumptions on the behaviors of family business employees and on the role of independent directors inside the firm. Stewardship theory is anchored in a humanistic model where people are motivated by serving others. The organization is seen as an involvement oriented and empowering structure where mutual trustbased relationships are developed. Organizational members work as a collective, are trustworthy, and display pro-organizational conduct (Davis et al., 1997).

When applied to family firms, stewardship theory suggests that relationships inside the family business will be dominated by reciprocal altruism and a participative strategy (Corbetta and Salvatto, 2004b). Because of their emotional and social attachment to the business, family members practice self-restraint and carefully consider the consequences of their actions on the firm (Eddeltson \& Kellermanns, 2007). The use of participative strategies that empowers employees can lead them to be more engaged in the long-term strategy of the business and to have greater commitment and motivation to work in the business (Davis et al., 1997; Zahra, 2003). For instance, research shows that identification with the family firm and commitment to family business prosperity and success are common traits of family business managers (Davis, 
Allen, \& Hayes, 2010). This in turn leads family employees to place the business objectives ahead of their own (Miller \& Le Breton-Miller, 2005; Salloum, Bouri, \& Samara, 2013). Practices such as the ones described above enable family businesses to develop an important source of competitive advantage over their non-family counterparts (Corbetta \& Salvatto, 2004b) by reducing relationship conflict inside the business and by increasing collaboration, harmony, and knowledge sharing between employees (Eddeltson and Kellermanns, 2007).

Through stewardship theory lenses, the essential role of independent directors is not to provide contractual controlled monitoring. Instead, controlling owners mostly rely on trust-based monitoring. Independent directors are appointed on the board for their ability to provide service and advice to shareholders. Therefore, the presence of independent directors is considered as an added value for the company because they are able to bring industry-specific expertise that cannot be obtained by the virtue of insiders or affiliates appointment on the board (Anderson \& Reeb, 2004; Corbetta \& Salvato, 2004b; Garcia-Ramos \& Garcia-Ollala, 2011).

\subsection{Complementarity of Agency and Stewardship Theories Predictions}

When compared, agency and stewardship theories differ in their consideration of two elements: the attitudes of family business employees inside the business (i.e. opportunistic agents/good stewards) and the role of independent directors (i.e. controlled monitoring/service

and advice) on the board. Table 1 summarizes the main behavioral assumptions of agency and stewardship theories.

[Table 1 here]

As previously argued and as shown in Table 1, competing arguments and conflicting results surround the relationship between the presence of independent directors on the board and family business performance. Plausibly, the main reason for these competing views is that 
research has so far considered family businesses as a homogenous group. However, recent works indicate that family businesses are a group of heterogeneous companies (Chrisman \& Patel, 2012; Garcia-Castro and Aguilera, 2014) with different governance structures and needs (Corbetta and Salvatto, 2004a). In other words, the recommendation of having independent directors on the board does not fit all family businesses. This increases the need to explore how the combination of different family business governance structures can shape the effect of independent directors on family business performance. Theoretically, a starting point to account for family business heterogeneity is not to consider family business protagonists exclusively as agents or stewards. Different cultural and governance contingencies can shape the attitude of family members inside the business (Chen et al., 2002: Ashforth \& Mael, 1989). In the next sections we elaborate on these issues.

\section{Agency and Stewardship in Collectivist Family Businesses}

Three reasons motivate the exploration of the Collectivist national cultural setting. First, the domination of family businesses as an organizational form is greater in Collectivist cultures than in Individualist cultures (Chakrabarty, 2009); yet, few studies built theory considering this distinct cultural setting (Pagliarussi \& Rapozo, 2011; Sharma \& Manikutty, 2005). Second, the Collectivist cultural setting is more predictive than other cultural dimensions in managerial decision making (Crossland \& Hambrick, 2011), being considered as a core dimension for distinguishing cultures (e.g. Cannon, Doney, Mullen, \& Petersen, 2010), and appearing in several recognized frameworks in the literature as a predictor of family employees' behaviors (e.g. Pagliarussi \& Rapozo, 2011; Sharma \& Manikutty, 2005). Third, Collectivism shapes the role of the family in the workplace, hints at the prevailing family structure (Hofstede, 1984; Sharma \& Manikutty, 2005), and suggests that the adoption of agency or stewardship as an 
adequate theoretical framework is contingent upon the other with whom the interaction occurs (Chen et al., 2002; Hofstede, 1984).

An important implication of the family business embeddedness in a Collectivist culture is that family members will prioritize the in-group interest over their self-interest (Husted \& Allen, 2008; Triandis, 1995). At the same time, in-groups will regard people that have no prior relationship with them as part of the out-group. In-groups will form higher prejudice and formalization when dealing with people from the out-group (Chen et al., 2002; Hofstede, 1984). This results into two potential configurations: 1) the formation of a mixed organizational culture inside the family firm where a clan and adhocracy based organizational culture is dominant when interactions occur between members of the in-group, or 2) a market and hierarchical culture will be dominant when interactions occur between members of the out-group (Corbetta and Salvatto, 2004b; Hofstede, 1984; Quinn \& Cameroon, 2006). While the former configuration has been shown to facilitate relationship exchange and tacit firm knowledge sharing, the latter (a market and hierarchy culture) has been found to negatively impact tacit knowledge sharing among individuals (Suppiah \& Singh Sandhu, 2011). In this last situation, when family members deal with people from the out-group an agency environment is likely to occur (Ashforth \& Mael, 1989; Chen et al., 2002). However, when interactions occur between members of the in-group, stewardship behaviors are more likely to be dominant. In a Collectivist culture, people treat insiders with particularistic criteria showing them reciprocal altruistic attitudes emphasized by mutual support and a willingness to attend other insiders' needs (Chen et al., 2002).

\section{Governance Contingencies that Shape the Effect of Independent Directors on Family}

\section{Firms Performance}


This section builds on the previously contextualized agency and stewardship theoretical frameworks to discuss several governance contingencies that shape the effect of independent directors on family firm performance.

\subsection{Family ownership}

When the business is $100 \%$ owned by the same extended family, family business employees will more likely regard the business as an economic wealth generating institution for all family members (Herrero, 2011; Miller et al., 2013). Absolute family ownership of the business implies that gains and losses coming from the business revenues will be directly endured by the family, giving family employees strong incentives to reciprocate altruism (Demsetz \& Lehn, 1985; Eddleston \& Kellermanns, 2007). The principal-principal conflict of interest that results from the presence of minority shareholders and/or different extended family groups owning the business is automatically nullified. For example, there is no need for the family to try to extract private rents through special dividends as the family is likely to directly benefit from the reinvestment of profits in the business. This leads family members involved in the business to have less incentives to show opportunistic behavior and more incentives to show stewardship behaviors (Herrero, 2011). As a result, the presence of independent directors becomes an additional unnecessary cost for the family firm.

Conversely, when the business is less than $100 \%$ family owned, Anderson \& Reeb (2004) suggest that independent directors tend to protect minority shareholders' interests against selfserving behavior of the majority controlling owners. Specifically, when businesses are privately held, a conflict of interest is likely to occur when different extended families share business ownership (Pagliarussi \& Rapozo, 2011). Managers and directors coming from different extended families might find difficult to monitor other family members working in the 
organization. The latter statement is exemplified by the words of a family manager in Brazil discussing his incapacity to monitor the work behavior of the son of his business partner: "How am I going to tell the son of my partner-someone I love, that I treat like a brother- that he can't act a certain way? How am I going to tell him he's wrong if he thinks he can manage a company while only arriving at 10 in the morning? If I said anything it would hurt his father, see?" (Pagliarussi \& Rapozo, 2011, p.178). All these elements increase the family business need for contractual controlled monitoring by independent directors as a way to protect the company against the risk of having different extended families each of whom seeks to achieve its own private family benefits regardless of the company interests (Villalonga \& Amit, 2006). Therefore, we argue that the presence of independent directors helps improve firm performance.

\subsection{Family Management}

When the business is $100 \%$ family owned and there is a high family involvement in management, family members are able to perform the role of independent directors. Driven by their perception of the business as a wealth generating institution, family employees have incentives to monitor other non-family employees (Anderson et al., 2009) and to draw on their privileged access to exclusive networks, personal relationships (Zahra, 2010), and family derived social capital (Arregle, Hitt, Sirmon, \& Very, 2007) to provide service and advice the firm. In this context, the risk of family employees to perceive independent directors as people who are there to interfere in their family affairs increases (Westphal, 1999) resulting in increased tensions inside the family business. For example the founder of Otsuka Kagu, a Japanese furniture producer, fired his daughter from her managerial position for bringing an outside director to sit alongside family members on the firm's board (Economist, 2015, p.52). From these arguments, it 
can be inferred that the presence of independent directors can lead to an increase in costs and a decrease in firm performance (Jaskiewizk \& Klein, 2007; Corbetta \& Salvato, 2004a).

However, low family involvement in management creates the risk of having unmonitored non-family agents. As family involvement in management decreases, the ability of obtaining benefits from the family derived social capital decreases and the need for monitoring, service and advice by independent directors' increases (Anderson \& Reeb, 2004). Tensions that may arise between family members and independent directors are also automatically reduced. Therefore, the presence of independent directors becomes essential to achieve better firm performance.

\subsection{Founder CEO}

Founder led family businesses are able to capitalize on parental altruism which facilitates trust, knowledge sharing, and reciprocity among family members (Garcia- Ramos and GarciaOllalla, 2011). Because of their superior emotional attachment and their identification with the firm, founders have the power and the incentive to monitor firm employees and to use their social capital to direct the business towards achieving optimal performance (e.g. Dyer, 1988; Miller et al., 2013). Therefore, when founders are still involved as CEOs of the family business, the need for the services of independent directors is reduced.

However, when founders are no longer present in the firm, the power and incentives for future generations to perform independent directors' role are reduced (Lubatkin, Schulze, Ling, \& Dino, 2005; Bammens, Voordeckers, \& Van Gils, 2008). When firm ownership is shared between different extended family business groups, there is a risk of a principal-principal conflict of interest between different family members involved in the business. A conflict of interest might initiate between family members of different generations as they pursue their own family 
interests on the detriment of other family shareholders involved in the business and, eventually, on the detriment of the firm (Basco \& Voodrdeckers, 2015). Consequently, this increases the need independent directors' services to achieve better performance.

\subsection{Board Size}

When the board is small, research shows a higher alignment of interest between principals and agents which eliminates the need for formal monitoring (Jaskiewicz \& Klein, 2007). If this condition is coupled with the presence of family directors that are using their family derived social capital to provide service and advice for the firm, the presence of independent directors can become an additional unnecessary cost.

Empirical research shows that larger boards are associated with less alignment of interest between ownership and management (Jaskiewicz \& Klein, 2007). Specifically, larger boards inhibit individual responsibility as it becomes more difficult to hold directors responsible for family business performance outcomes. This situation creates the risk of opportunistic behavior or neglect of duties (Lane, Astrachan, Keyt, \& McMillan, 2006). Consequently, under this lens the need for independent directors services increases.

\subsection{Independent Directors}

Based on the previous argumentation the presence of independent directors on the family business board can be considered as a double-edged sword. Depending on the combination of several governance contingencies, the presence of independent directors has the potential to increase or decrease firm performance. In the following, this paper explores different governance configurations that can shape the effect of independent directors on family business performance. 


\section{Data and Method}

\subsection{Data}

The Middle East provides an understudied geographical context where family businesses are rooted historically and economically (Welch \& Raven, 2006). Specifically, this paper focuses on Lebanon, a Collectivist culture where families dominate political rule and business ownership (Welch \& Raven, 2006). Although an interesting and special environment where several new insights can be gained (Zahra, 2011), the Middle East is an extremely challenging empirical setting since response rate to mail surveys is low and archival data is rare and questionable in quality (Welch \& Raven, 2006; Zahra, 2011). To deal with this complex situation, a database was purchased from www.reachgulfbusiness.com. This website offers personal contact names, phone numbers, and emails of owners and managers of Lebanese companies. The database included 3951 Lebanese companies. Given the challenging nature of data collection through mail surveys in the Middle East (Zahra, 2011), this paper follows Arosa et al. (2010) by collecting survey data through telephone interviews. All interviews were done in English language. There was no language barrier in the interviews as the majority of Lebanese business owners, managers, and employees speak and understand English language. Considering cost efficiencies, 100 companies that have the legal form of "Lebanese Joint Stock Company" were selected and contacted. We chose this specific legal form of companies as they are forced by law to have a board of directors. 77 companies agreed to participate in the survey. Data was collected during the months of May and June, 2016. To limit the threat of social desirability, we guaranteed respondent anonymity to all the interviewees before starting data collection. Guarantying anonymity has been argued to reduce the threat of common method bias (Podsakoff \& Organ, 1986; Podsakoff et al., 2003). 
The dataset included privately held family businesses which are an understudied population (Carney, Van Essen, Gedajlovic, Heugens, 2015) that largely dominate the Lebanese economy. The analysis was also limited to companies that have at least $25 \%$ family ownership and at least one family member in the management team of the business. These are the two criteria that are most adopted in the literature to identify family firms (De Massis, Sharma, Chua, \& Chrisman, 2012). Three companies were eliminated because they had less than one family member in the management team or because the family owned less than $25 \%$ of the business. The final sample included 74 Lebanese private Joint Stock Companies. More than $75 \%$ of the respondents were either shareholders, and/or members of the management teams, and/or members of the board of directors. The remaining respondents were firm employees with at least two years of experience. Respondents were thus well informed about the company characteristics. In terms of company age, the sample covered a wide range of companies. The oldest company was founded in 1857 and the youngest company was founded in 2014. Table 2 and Table 3 show the distribution of companies in terms of the sector of activity and the education level of the respondents, respectively.

[Table 2 here]

[Table 3 here]

As shown in Table 2, companies surveyed are highly diversified in terms of sector and show an accurate representation of sectors commonly found in the Lebanese economy (Salloum et al., 2013) increasing the external validity of the study. Table 2 also reveals that all respondents had a good educational level, corroborating that respondents were qualified to understand and answer questions related to business governance and performance. 


\subsection{Philosophical assumptions regarding the nature of social reality}

This paper adopts a positivist philosophical approach to fill a void in existing knowledge. The phenomenon is examined in its naturalistic context with the purpose of confronting theory with the empirical reality (Piekkari, Welch, \& Paavilainen, 2009). Reality is considered as objective and the research purpose is to generate knowledge "in the form of measurable regularities, laws and patterns" (Leppäaho et al., 2016, p.2) that allows for a replication logic and for the search for general patterns (Langley \& Abdallah, 2011).

\subsection{Method}

Based on the positivist philosophical orientation and consistent with the aim to explore how the combination of different governance contingencies shape the effect of independent directors on family business performance, this paper uses qualitative comparative analysis (QCA). Because the management field is causally complex (Kostova \& Zaheer, 1999), it requires alternative analytical methods. QCA fills this gap by offering a series of advantages over traditional multiple regression analysis (Woodside, 2013). First, comparative research methods such as QCA are particularly suitable for multilevel explanations and influences. QCA overcomes the limitations coming from linearity and complementary associations between variables by assuming asymmetrical relationships (Fiss, 2011). That is, QCA does not require researchers to assume that the antecedent conditions (the independent variables) are only linearadditive, but rather necessitates the analysis of net effects (Mills et al., 2006). Second, while in regression analysis the main goal is to discover the effect of a variable on a particular outcome, in QCA the focus is on what combination of antecedent conditions lead to a given outcome (Longest \& Vaisey, 2008). Third, QCA entails equifinality, meaning that there are multiple paths (configurations or causal recipes in QCA terminology) that can conduce to the same outcome. 
Feasible recipes are not just combinations of antecedent conditions (either positive or negative) but also of their absence (Wu, Yeh, \& Woodside, 2014). Lastly, QCA has the advantage of performing well with large and small samples, allowing the generalization of findings to populations (Fiss, 2011). Hence, all these elements make the QCA method particularly relevant and mostly appropriate for this study.

QCA requires expressing variables into sets according to their degree of membership to a specific condition. Scores range from "1" (full membership) to "0" (full non-membership). Cutoff points allow calibrating all values into membership values. Usually, 0.95 indicates full membership, 0.05 full non-membership and 0.5 the cases with the maximum ambiguity (Ragin, 2009). The building and analysis of the truth table constitutes the next step. This data matrix has $2^{\mathrm{k}}$ rows, where $k$ is the number of causal conditions in the analysis. The range of conditions in the analysis defines a property space with $k$ dimensions. Consequently, the property space is a vector space with two corners corresponding to the locations. Each row reflects a specific combination of attributes, and each column represents a condition. Each case belongs to the combination in which its membership score is greater than 0.5 (Fiss, 2011). The next step is to reduce the number of rows in the truth table. Although several algorithms can logically minimize a truth table, the most common choice in fsQCA is a version of the Quine-McCluskey algorithm (Quine, 1952). Using Boolean algebra, this algorithm returns a set of combinations of causal conditions, each combination minimally sufficient to produce the outcome.

QCA uses Boolean algebra to compute the commonalities among the configurations that lead to the outcome. With fuzzy set QCA the Quine-McCluskey algorithm performs the logical reduction of statements (Fiss, 2007). Two parameters indicate the goodness of fit of the final solution: coverage and consistency. The former expresses the empirical relevance of a solution 
and is analogous to the effect size in statistical hypothesis testing. Consistency quantifies the extent to which cases sharing similar conditions present the same outcome and is analogous to significance metrics in statistical hypothesis testing (Wu et al., 2014).

\subsection{Measures}

The outcome measure is the performance of Lebanese family firms. Given that companies surveyed were privately held, it is difficult to collect objective economic performance measures (Love, Priem, Lumpkin, 2002) especially in the Middle East where people are more conservative about sharing sensitive information (Zahra, 2011). Accordingly, this study follows the recommendations of Dess and Robinson (1984) and Eddleston and Kellermanns (2007). Dess and Robinson (1984) empirically show that subjective and objective performance measures are strongly correlated and have strong convergent validity. Accordingly, these authors suggest that subjective measures can serve as a remedy to measure firm performance when objective data are unavailable. Following this rationale, performance is captured through eight perceptual questions related to growth in sales, growth in market share, growth in employees, growth in profitability, return on equity, return on total assets, profit margin on sales, and the ability to fund growth from profits (Eddleston \& Kellermanns, 2007). Respondents were asked to rate their company along these dimensions compared to their closest competitors over the last 3 years $(2015,2014$, and 2013). Answers range in a 5-point Likert scale from "1" (much worse) to "5" (much better). Reliability of this performance measure was very high (Cronbach's $\alpha=0.92$ ) which is in line with previous studies that found similar high reliability (e.g. Eddleston \& Kellermanns, 2007; Love et al., 2002). Individual scores were then added to compute an overall performance score (Dess \& Robinson, 1984; Eddleston \& Kellermanns, 2007; Love et al., 2002). By asking respondents to rate their company performance in comparison to its closest competitors, firm size 
and industry effects are automatically controlled for (Eddeltson \& Kellermanns, 2007; Love et al., 2002).

Consistent with the previously outlined argumentation, this study uses 5 causal conditions to explain the outcome: family ownership, family management, founder involvement in the business as a CEO of the family firm, board size, and the presence of at least one independent director on the board. The questions asked to collect these data are displayed in Appendix A.

Although the presence of a family CEO and CEO duality can be important variables that affect performance (Bammens et al., 2008; Villalonga \& Amit, 2006), they are not included in the analysis since data did not display enough variability regarding these variables. In fact, $94.6 \%$ of the cases display CEO duality and $95.9 \%$ of the cases have a family member as a CEO. These two conditions are very common in the Lebanese economy. We triangulated the data collected about the governance structure of companies by verifying the answers of respondents through the website www.kompass.com. This website provides information about the full names of the top management team and the board members of the company which we used as a proxy to determine the number of family members in the top management team and the number of family members on the board of directors. The answers provided in the phone interviews and the information available on the website were completely congruent.

Table 4 shows the transformation of the outcome and the antecedent conditions into fuzzy or crisp set terms. The way fuzzy variables are operationalized is consistent with our argumentation and with previous literature on family firms (Kraus et al., 2016).

[Table 4 here] 


\subsection{Results}

Because QCA assumes complex causality and focuses on asymmetric relationships, the QCA methodology requires the analysis of necessary conditions to produce the outcome (Meyer, Tsui, \& Hinings, 1993). A condition is necessary when its consistency score is equal or above 0.9 (Schneider \& Wangemann., 2010). Table 4 summarizes the consistency and coverage values for all antecedent conditions. As the highest consistency value among all conditions is 0.7201 , none of the variables is a necessary condition to produce the outcome.

[Table 4 here]

Table 5 displays the results of the intermediate solution as recommended by Ragin's (2009). Using the notation introduced by Ragin \& Fiss (2008), black circles $(\bullet)$ denote the presence of a condition, white circles $(\mathrm{O})$ represent its absence, and blank cells indicate that the condition is not binding in that particular configuration.

[Table 5 here]

Six different causal paths lead to the outcome (i.e. performance) and four of them present acceptable consistency indices. Raw coverage indices range from 0.04 to 0.23 . This variety of recipes suggests that these configurations are sufficient but not necessary. Consequently, no unifying causal governance recipe explains alone family business performance. 
Following Ragin's (2008) recommendation, the causal paths with high raw coverage (configurations \#1, \#2 and \#5) deserve further attention. This translates into saying that these configurations are the most meaningful ones in explaining the outcome and cover the greatest proportion of cases that can be explained exclusively by these recipes. Particularly, the first two recipes converge in suggesting that when the business is less than $100 \%$ family owned and when there is low involvement of family members in the management team, the presence of independent directors' becomes a necessary condition to achieve good performance. The main difference between the two configurations is found in the absence of the founder as the CEO (configuration \#1) and in having a large board (configuration \#2). In fact, large boards are significantly linked to the age of the firm (Jaskiewicz \& Klein, 2007). Hence, configuration \#2 signals that the business has been inherited by future generations and is thus congruent with configuration \#1. Configuration \#5 also displayed high consistency (0.92) and thus deserves further attention. This causal path is interesting as it suggests that under the conditions of $100 \%$ family ownership, high family involvement in management, and the presence of a large board, the absence of independent directors is necessary to have good firm performance.

Three further robustness tests were performed. In the first one the frequency of cases (3) and the consistency threshold (0.75) were changed. As it can be seen in Appendix B Table 7, results are mostly congruent with the above reported recipes. In the second robustness test we have calculated the average age of companies (35 years old) and we have split the sample between older ( $>35$ years) and younger ( $<35$ years) companies. As shown in Tables 8 and 9 in Appendix B, configurations that display acceptable coverage and consistency values indicate that old companies are more likely to have independent directions-probably because the founder is retired or has deceased-. In the third robustness check we have replaced independent directors by 
affiliates who usually have larger tenure on the board of directors (Jones et al., 2008). As it can be seen in Appendix B Table 10, under these circumstances the solution coverage drops to 0.3515 not meeting the recommended cut-off value. We therefore conclude that the outcome is better modelled when including in the analysis independent directors, who usually have shorter tenures than affiliates.

\section{Discussion}

This paper started by highlighting that the relationship between the presence of independent directors on the board and family business performance is still theoretically debated and empirically inconclusive. Accordingly, the question has shifted from simply asking "how will the presence of independent directors affect family business performance?" to discussing the circumstances under which independent directors presence should be considered as an opportunity or a threat for achieving desired family business performance. Despite the many theoretical arguments (Corbetta \& Salvato, 2004a; Nordqvist et al., 2014) and anecdotal evidence (Samara \& Arenas, 2017) that suggest that the presence of independent directors might not be beneficial to all family businesses, to the best of our knowledge, this is the first paper that empirically explores when the presence of independent directors on the board should be considered as an asset or a liability for family firms. As nicely expressed by Corbetta and Salavato (2004a, p.120): "no single corporate governance arrangement can fit the multifaceted needs of companies embedded in different cultural, historical, and institutional settings". Hence, exploring the need for independent directors across different combinations of family business governance structures in an understudied yet intriguing Collectivist culture constitutes an important contribution to the family business literature. Results show that independent directors can contribute to firm performance when the company is less than $100 \%$ owned by the same 
family, when family involvement in management is low, and when the company grows old and the founder is no longer involved in its operations. At the same time, independent directors will not be needed and can even be considered as a threat for firm performance when the company is $100 \%$ owned by the same family, when family involvement in management is high, and when the board of directors is large and dominated by family members and/or affiliates.

These findings empirically validate the ability of agency and stewardship theories to offer mutual enabling explanations of family business behavior (Madison et al., 2016). Hence, rather than arguments based in stewardship theory and agency theory being presented as a dichotomy, our research demonstrates that both theoretical threads anchored in agency theory and in stewardship theory can be relevant in accounting for the results obtained from different configurations. Therefore, future research should consider using these two threads complimentarily rather than choosing one or the other as mutually exclusive frames.

For practitioners, these findings inform family business owners, advisors, and policy makers embedded in the Middle East region that they must pay careful attention to the family business governance structure before deciding/advising/recommending the appointment of independent directors on the board. Moreover, although families live in the larger cultural setting, the mind-sets and reactions of family business employees can significantly be influenced by the family structure. Extended family structures that dominate Collectivist cultures can also be present in Individualist cultures (Sharma \& Manikutty, 2005). Therefore, policy makers and practitioners worldwide must make careful consideration to the above outlined contingencies before recommending the presence of independent directors on the family business board.

Configuration \#1 and configuration \#2 (Table 6) show that the presence of independent directors is a necessary condition to achieve better performance when the business is less than 
$100 \%$ family owned, when family involvement in management is low and when future generations become involved in the business. This finding is in line with the thesis of Anderson and Reeb (2004) stating that the presence of independent directors is essential for firm performance when a conflict of interest between minority and majority shareholders is likely to occur. We contribute to this conversation by arguing that, in the context of privately held family businesses embedded in Collectivist cultures, the principal-principal agency problem may also arise when different extended family groups share business ownership. When this condition is coupled with the absence of the founder and low family involvement in management, the findings of this paper suggest that the presence of independent directors becomes essential to achieve better firm performance. Congruent with both agency and stewardship theories, under the aforementioned conditions, the family business will need independent directors to monitor its non-family top management team (Jensen \& Meckling, 1976) to mitigate the principal-principal conflict of interest (Anderson \& Reeb, 2004; Pagliarussi \& Rapozo, 2011) and to provide industry specific expertise (Corbetta \& Salvatto, 2004b).

However, as suggested by configuration \#5, when the family owns $100 \%$ of the business, when family involvement in management is high, and when future generations take control of the business, the absence of independent directors becomes a necessary condition for better firm performance. This finding converges with the work of Herrero (2011) who shows that, in small family businesses, agency costs are significantly reduced. Results of this paper extend the finding of Herrero (2011) by showing that, when the business is $100 \%$ family owned and when family involvement in management is high, the need for independent directors is not only reduced but can also lead to a decrease in firm performance. This finding can be attributed to the Collectivist geographical cultural context in which Lebanese family businesses are embedded 
(Hofstede, 1984). As previously argued, in Collectivist cultures, strong in-group/out-group perceptions are likely to be formed (Chen et al., 2002). Family members are likely to consider their blood-related relatives, family friends, and business partners as part of the "in-group" and people that have no prior relationship with the family or the business as part of the "out-group" (Ashforth \& Mael, 1989). As future generations take control of the business, family business executives may accumulate specific knowledge of the firm and independent directors may lack the understanding of family dynamics (Garcia-Ramos \& Garcia-Ollala, 2011; Harris \& Raviv, 2008), both of which are crucial for family businesses performance (Sharma \& Manikutty, 2005). We contribute to this debate by posing that, in Collectivist cultures, family managers will tend to discriminate against independent directors (Ashforth, \& Mael, 1989). Therefore, the presence of independent directors decreases cooperation and knowledge sharing inside the family business and eventually leads to a decrease in performance.

\section{Limitations and future research}

This study is subject to some limitations that open up new lines for future research. First, in terms of external validity, the sample only includes Lebanese companies. Hence, it would be interesting to replicate this study in other Collectivist countries. While the Lebanese Collectivist cultural setting is similar to that of the Arab world, it would be interesting to replicate this study in other Collectivist geographical settings such as India, China, Japan, or Latin America where the countries score for Collectivism can even be higher than that of the Middle East region. Relatedly, future research can perform a cross-cultural study in Individualist and Collectivist countries which will contribute to increase existing knowledge about different family business governance needs across cultures. 
Second, given the difficulty of collecting data from the Middle East (Zahra, 2011), the survey was answered by a single respondent. Although anonymity was assured prior to the phone interviews and although most respondents occupied top managerial positions and were aware of business performance, common method bias can constitute a threat for the internal validity of the results. Triangulating our results with objective data would have been desirable, but given that all the companies surveyed were privately held, public and secondary data were not accessible.

Third, fuzzy methods are sensitive to set calibration. While we have tried to remedy this threat by performing several robustness tests, the presence of clear guidelines in family business research on how to calibrate fuzzy sets will significantly increase the ability of researchers to reach better membership breakpoints (Garcia-Castro \& Aguilera, 2014).

\section{References}

Agrawal, A., \& Knoeber, C.R. (1996). Firm performance and mechanisms to control agency problems between managers and shareholders. Journal of financial and quantitative analysis, 31(03), 377-397.

Anderson, R. C., \& Reeb, D. M. (2004). Board composition: Balancing family influence in S\&P 500 firms. Administrative Science Quarterly, 49(2), 209-237.

Anderson, R. C., Duru, A., \& Reeb, D. M. (2009). Founders, heirs, and corporate opacity in the United States. Journal of Financial economics, 92(2), 205-222.

Arregle, J. L., Hitt, M. A., Sirmon, D. G., \& Very, P. (2007). The development of organizational social capital: Attributes of family firms. Journal of management studies, 44(1), 73-95.

Arosa, B., Iturralde, T., \& Maseda, A. (2010). Ownership structure and firm performance in nonlisted firms: Evidence from Spain. Journal of Family Business Strategy, 1(2), pp.88-96.

Ashforth, B. E., \& Mael, F. (1989). Social identity theory and the organization. Academy of management review, 14(1), 20-39.

Bammens, Y., Voordeckers, W., \& Van Gils, A. (2008). Boards of directors in family firms: A generational perspective. Small Business Economics, 31(2), 163-180.

Bammens, Y., Voordeckers, W., \& Van Gils, A. (2011). Boards of directors in family businesses: A literature review and research agenda. International Journal of Management Reviews, 13(2), 134-152. 
Breton-Miller, L., \& Miller, D. (2009). Agency vs. stewardship in public family firms: A social embeddedness reconciliation. Entrepreneurship Theory and Practice, 33(6), 1169-1191.

Cannon, J. P., Doney, P. M., Mullen, M. R., \& Petersen, K. J. (2010). Building long-term orientation in buyer-supplier relationships: The moderating role of culture. Journal of Operations Management, 28(6), 506-521.

Carney, M., Van Essen, M., Gedajlovic, E. R., \& Heugens, P. P. (2015). What do we know about private family firms? A meta-analytical review. Entrepreneurship Theory and Practice, 39(3), 513-544.

Chakrabarty, S. (2009). The influence of national culture and institutional voids on family ownership of large firms: A country level empirical study. Journal of International Management, 15(1), 32-45.

Chen, C. C., Peng, M. W., \& Saparito, P. A. (2002). Individualism, collectivism, and opportunism: A cultural perspective on transaction cost economics. Journal of Management, 28(4), 567-583.

Chrisman, J. J., Chua, J. H., \& Litz, R. A. (2004). Comparing the agency costs of family and non-family firms: Conceptual issues and exploratory evidence. Entrepreneurship Theory and practice, $28(4), 335-354$.

Chrisman, J. J., Sharma, P., \& Taggar, S. (2007). Family influences on firms: An introduction. Journal of Business Research, 60(10), 1005-1011.

Chrisman, J. J., \& Patel, P. C. (2012). Variations in R\&D investments of family and nonfamily firms: Behavioral agency and myopic loss aversion perspectives. Academy of management Journal, 55(4), 976-997.

Chrisman, J. J., Sharma, P., Steier, L. P., \& Chua, J. H. (2013). The influence of family goals, governance, and resources on firm outcomes. Entrepreneurship Theory and Practice, $37(6), 1249-1261$.

Chrisman, J. J., Memili, E., \& Misra, K. (2014). Nonfamily managers, family firms, and the winner's curse: The influence of noneconomic goals and bounded rationality. Entrepreneurship Theory and Practice, 38(5), 1103-1127.

Chua, J. H., Chrisman, J. J., \& Bergiel, E. B. (2009). An agency theoretic analysis of the professionalized family firm. Entrepreneurship Theory and Practice, 33(2), 355-372.

Corbetta, G., \& Salvato, C. A. (2004a). The Board of Directors in family firms: one size fits all?. Family Business Review, 17(2), 119-134.

Corbetta, G., \& Salvato, C. (2004b). Self-serving or self-actualizing? Models of man and agency costs in different types of family firms: A commentary on "Comparing the Agency Costs 
of Family and Non-family Firms: Conceptual Issues and Exploratory Evidence". Entrepreneurship Theory and Practice, 28(4), 355-362.

Crossland, C., \& Hambrick, D. C. (2011). Differences in managerial discretion across countries: how nation-level institutions affect the degree to which CEOs matter. Strategic Management Journal, 32(8), 797-819.

Cuadrado-Ballesteros, B., Rodríguez-Ariza, L., \& García-Sánchez, I. M. (2015). The role of independent directors at family firms in relation to corporate social responsibility disclosures. International Business Review, 24(5), 890-901.

Dalton, D. R., Daily, C. M., Ellstrand, A. E. \& Johnson, J. L. (1998). Meta-analytic reviews of board composition, leadership structure, and financial performance. Strategic management journal, 19(3), 269-290.

Davis, J. H., Schoorman, F. D., \& Donaldson, L. (1997). Toward a stewardship theory of management. Academy of Management review, 22(1), 20-47.

Davis, J. H., Allen, M. R., \& Hayes, H. D. (2010). Is blood thicker than water? A study of stewardship perceptions in family business. Entrepreneurship Theory and Practice, 34(6), 1093-1116.

Dawson, A. (2012). Human capital in family businesses: Focusing on the individual level. Journal of Family Business Strategy, 3(1), 3-11.

De Massis, A., Sharma, P., Chua, J. H., \& Chrisman, J. J. (2012). Family business studies: An annotated bibliography. Edward Elgar Publishing.

Demsetz, H., \& Lehn, K. (1985). The structure of corporate ownership: Causes and consequences. Journal of Political Eonomy, 93(6), 1155-1177.

Dess, G. G., \& Robinson, R. B. (1984). Measuring organizational performance in the absence of objective measures: the case of the privately-held firm and conglomerate business unit. Strategic management journal, 5(3), 265-273.

Dyer, W. G. (1988). Culture and continuity in family firms. Family Business Review, 1(1), 3750.

Economist. (2015). Winds of change, 415(8941), 51-53.

Eddleston, K. A., \& Kellermanns, F. W. (2007). Destructive and productive family relationships: A stewardship theory perspective. Journal of Business Venturing, 22(4), 545-565.

Evert, R. E., Martin, J. A., McLeod, M. S., \& Payne, G. T. (2016). Empirics in family business research: Progress, challenges, and the path ahead. Family Business Review, 29, 17-43. 
Fama, E. F., \& Jensen, M. C. (1983). Agency problems and residual claims. The Journal of Law \& Economics, 26(2), 327-349.

Fiss, P. C. (2007). A set-theoretic approach to organizational configurations. Academy of management review, 32(4), 1180-1198.

Fiss, P. C. (2011). Building better causal theories: A fuzzy set approach to typologies in organization research. Academy of Management Journal, 54(2), 393-420.

Forbes Middle East. (2014). Top 100 private companies making an impact in the Arab world. http://www.forbesmiddleeast.com/en/lists/.

Garcia-Castro, R., \& Aguilera, R. V. (2014). Family involvement in business and financial performance: A set-theoretic cross-national inquiry. Journal of Family Business Strategy, $5(1), 85-96$.

García-Ramos, R., \& García-Olalla, M. (2011). Board characteristics and firm performance in public founder-and nonfounder-led family businesses. Journal of Family Business Strategy, 2(4), 220-231.

Gnan, L., Montemerlo, D., \& Huse, M. (2015). Governance systems in family SMEs: The substitution effects between family councils and corporate governance mechanisms. Journal of Small Business Management, 53(2), 355-381.

Harris, M., \& Raviv, A. (2008). A theory of board control and size. Review of Financial Studies, 21(4), 1797-1832.

Herrero, I. (2011). Agency costs, family ties, and firm efficiency. Journal of Management, 37(3), 887-904.

Hofstede, G. (1984). Culture's consequences: International differences in work-related values (Vol. 5). Sage.

Huarng, K.-H. (2015). Re-examining the Consistency in fsQCA. In D. Palacios-Marqués, D. Ribeiro Soriano \& K. H. Huarng (Eds.), New Information and Communication Technologies for Knowledge Management in Organizations (pp. 102-109). Springer.

Husted, B. W., \& Allen, D. B. (2008). Toward a model of cross-cultural business ethics: The impact of individualism and collectivism on the ethical decision-making process. Journal of Business Ethics, 82(2), 293-305.

Jaskiewicz, P., \& Klein, S. (2007). The impact of goal alignment on board composition and board size in family businesses. Journal of Business Research, 60(10), 1080-1089.

Jensen, M. C. \& Meckling, W. H. (1976). Theory of the firm: Managerial behavior, agency costs and ownership structure. Journal of Financial Economics, 3(4), 305-360. 
Jones, C. D., Makri, M., \& Gomez-Mejia, L. R. (2008). Affiliate directors and perceived risk bearing in publicly traded, family-controlled firms: The case of diversification. Entrepreneurship Theory and Practice, 32(6), 1007-1026.

Kraus, S., Mensching, H., Calabrò, A., Cheng, C. F., \& Filser, M. (2016). Family firm internationalization: A configurational approach. Journal of Business Research.

Kuo, Y. P., \& Hung, J. H. (2012). Family Control and Investment-Cash Flow Sensitivity: Moderating Effects of Excess Control Rights and Board Independence. Corporate Governance: An International Review, 20(3), 253-266.

Lane, S., Astrachan, J., Keyt, A., \& McMillan, K. (2006). Guidelines for family business boards of directors. Family Business Review, 19(2), 147-167.

Leppäaho, T., Plakoyiannaki, E., \& Dimitratos, P. (2016). The Case Study in Family Business: An Analysis of Current Research Practices and Recommendations. Family Business Review, 29(2), 159-173.

Longest, K. C., \& Vaisey, S. (2008). fuzzy: A program for performing qualitative comparative analyses (QCA) in Stata. Stata Journal, 8(1), 79.

Love, L. G., Priem, R. L., \& Lumpkin, G. T. (2002). Explicitly articulated strategy and firm performance under alternative levels of centralization. Journal of Management, 28 (5), 611-627.

Lubatkin, M. H., Schulze, W. S., Ling, Y., \& Dino, R. N. (2005). The effects of parental altruism on the governance of family-managed firms. Journal of Organizational Behavior, 26(3), 313-330.

Madison, K., Holt, D. T., Kellermanns, F. W., \& Ranft, A. L. (2016). Viewing Family Firm Behavior and Governance Through the Lens of Agency and Stewardship Theories. Family Business Review, 29, 65-93.

Martin, G., Gómez-Mejía, L. R., Berrone, P., \& Makri, M. (2016). Conflict Between Controlling Family Owners and Minority Shareholders: Much Ado About Nothing?

Entrepreneurship Theory and Practice.

Meyer, A. D., Tsui, A. S., \& Hinings, C. R. (1993). Configurational approaches to organizational analysis. Academy of Management journal, 36(6), 1175-1195.

Miller, D., \& Le Breton-Miller, I. (2005). Managing for the long run: Lessons in competitive advantage from great family businesses. Harvard Business Press.

Miller, D., Minichilli, A., \& Corbetta, G. (2013). Is family leadership always beneficial? Strategic Management Journal, 34(5), 553-571. 
Mitchell, R. K., Morse, E. A., \& Sharma, P. (2003). The transacting cognitions of nonfamily employees in the family businesses setting. Journal of Business Venturing, 18(4), 533 551.

Nordqvist, M., Sharma, P., \& Chirico, F. (2014). Family firm heterogeneity and governance: A configuration approach. Journal of Small Business Management, 52(2), 192-209.

Pagliarussi, M. S., \& Rapozo, F. O. (2011). Agency relationships in a Brazilian multifamily firm. Family Business Review, 24(2), 170-183.

Piekkari, R., Welch, C., \& Paavilainen, E. (2009). The case study as disciplinary convention: Evidence from international business journals. Organizational Research Methods, 12, 567-589.

Pieper, T. M., Smith, A. D., Kudlats, J., \& Astrachan, J. H. (2015). The persistence of multifamily firms: Founder imprinting, simple rules, and monitoring processes. Entrepreneurship Theory and Practice, 39(6), 1313-1337.

Podsakoff, P. M., \& Organ, D. W. (1986). Self-reports in organizational research: Problems and prospects. Journal of management, 12(4), 531-544.

Podsakoff, P. M., MacKenzie, S. B., Lee, J. Y., \& Podsakoff, N. P. (2003). Common method biases in behavioral research: a critical review of the literature and recommended remedies. Journal of Applied Psychology, 88(5), 879.

Ragin, C. C. (2008). User's guide to fuzzy-set/qualitative comparative analysis. www.fsqca.com. From www.fsqca.com.

Ragin, C. C., \& Fiss, P. C. (2008). Net effects analysis versus configurational analysis: An empirical demonstration. Redesigning social inquiry: Fuzzy sets and beyond, 190-212.

Ragin, C.C. (2009). Qualitative comparative analysis using fuzzy sets. In B. Rihoux,, \& C.C. Ragin, (EDS). Configurational comparative methods: Qualitative comparative analysis (QCA) and related techniques (applied social research methods) (pp.87-121). Thousand oaks and London: Sage.

Salloum, C. C., Azoury, N. M., \& Azzi, T. M. (2013). Board of directors' effects on financial distress evidence of family owned businesses in Lebanon. International Entrepreneurship and Management Journal, 9(1), 59-75.

Salloum, C., Bouri, E., \& Samara, G. (2013). Impact of family involvement in ownership management and direction on financial performance of the Lebanese firms. International Strategic Management Review, 1(1), 30-41.

Samara, G., \& Arenas D. (2017) How and Why Should Fairness Be Practiced in the Family Business Workplace?. Business Horizons (forthcoming) 
Schulze, W. S., Lubatkin, M. H., Dino, R. N., \& Buchholtz, A. K. (2001). Agency relationships in family firms: Theory and evidence. Organization science, 12(2), 99-116.

Sharma, P. (2004). An overview of the field of family business studies: Current status and directions for the future. Family Business Review, 17(1), 1-36.

Sharma, P., \& Manikutty, S. (2005). Strategic divestments in family firms: Role of family structure and community culture. Entrepreneurship Theory and Practice, 29(3), 293-311.

Schneider, C. Q., \& Wagemann, C. (2010). Standards of good practice in qualitative comparative analysis (QCA) and fuzzy-sets. Comparative Sociology, 9(3), 397-418.

Triandis, H. C. (1995). Individualism \& collectivism. Westview press.

Villalonga, B., \& Amit, R. (2006). How do family ownership, control and management affect firm value? Journal of financial Economics, 80(2), 385-417.

Voordeckers, W., Van Gils, A., \& Van den Heuvel, J. (2007). Board Composition in Small and Medium-Sized Family Firms. Journal of Small Business Management, 45(1), 137-156.

Welsh, D. H., \& Raven, P. (2006). Family Business in the Middle East: An Eexploratory Study of Retail Management in Kuwait and Lebanon. Family Business Review, 19(1), 29-48.

Westphal, J. D. (1999). Collaboration in the boardroom: Behavioral and performance consequences of CEO-board social ties. Academy of Management Journal, 42(1), 7-24.

Woodside, A. G. (2013). Moving beyond multiple regression analysis to algorithms: Calling for adoption of a paradigm shift from symmetric to asymmetric thinking in data analysis and crafting theory. Journal of Business Research, 66(4), 463-472.

Wright, M., Chrisman, J. J., Chua, J. H., \& Steier, L. P. (2014). Family Enterprise and Context. Entrepreneurship Theory and Practice, 38(6), 1247-1260.

Wu, P. L., Yeh, S. S., \& Woodside, A. G. (2014). Applying complexity theory to deepen service dominant logic: Configural analysis of customer experience-and-outcome assessments of professional services for personal transformations. Journal of Business Research, 67(8), 1647-1670.

Zahra, S. A., \& Stanton, W. W. (1988). The implications of board of directors composition for corporate strategy and performance. International Journal of Management, 5(2), 229236.

Zahra, S. A., \& Pearce, J. A. (1989). Boards of directors and corporate financial performance: A review and integrative model. Journal of Management, 15(2), 291-334. 
Zahra, S. A. (2003). International expansion of US manufacturing family businesses: The effect of ownership and involvement. Journal of Business Venturing, 18(4), 495-512.

Zahra, S. A. (2010). Harvesting family firms' organizational social capital: A relational perspective. Journal of Management Studies, 47(2), 345-366.

Zahra, S. A. (2011). Doing research in the (new) Middle East: Sailing with the wind. The Academy of Management Perspectives, 25(4), 6-21. 


\section{List of Tables}

Table 1. Agency and Stewardship theories main behavioral assumptions and arguments

\begin{tabular}{|c|c|c|c|}
\hline & \multicolumn{2}{|c|}{ Agency Theory } & Stewardship Theory \\
\hline $\begin{array}{l}\text { Main } \\
\text { behavioral } \\
\text { assumption }\end{array}$ & \multicolumn{2}{|c|}{$\begin{array}{l}\text { People are self-interested and opportunistic } \\
\text { by nature }\end{array}$} & $\begin{array}{l}\text { People are stewards by nature } \\
\text { and are motivated by serving } \\
\text { others }\end{array}$ \\
\hline $\begin{array}{l}\text { Effect of } \\
\text { family } \\
\text { employment } \\
\text { inside the } \\
\text { business }\end{array}$ & $\begin{array}{l}\text { Automatic } \\
\text { alignment of } \\
\text { interest between } \\
\text { shareholders and } \\
\text { management. } \\
\text { Family managers } \\
\text { are able to monitor } \\
\text { other non-family } \\
\text { employees. }\end{array}$ & $\begin{array}{l}\text { Type one agency } \\
\text { problem: } \\
\text { entrenchment and } \\
\text { asymmetric altruism. } \\
\text { Type two agency } \\
\text { problem: a principal- } \\
\text { principal conflict of } \\
\text { interest between } \\
\text { family shareholders } \\
\text { and minority } \\
\text { shareholders/between } \\
\text { different family } \\
\text { groups owning the } \\
\text { business. }\end{array}$ & $\begin{array}{l}\text { Reciprocal altruism and a } \\
\text { participative strategy will } \\
\text { dominate business } \\
\text { relationships. } \\
\text { Emotional and social } \\
\text { attachment of family members } \\
\text { to the business. } \\
\text { Family members have more } \\
\text { commitment and motivation to } \\
\text { work in the business. }\end{array}$ \\
\hline $\begin{array}{l}\text { The role of } \\
\text { independent } \\
\text { directors }\end{array}$ & \multicolumn{2}{|c|}{$\begin{array}{l}\text { To provide a controlled monitoring for the } \\
\text { firm management team. }\end{array}$} & $\begin{array}{l}\text { To provide service, advice, and } \\
\text { industry-specific expertise. }\end{array}$ \\
\hline $\begin{array}{l}\text { The effect of } \\
\text { independent } \\
\text { directors }\end{array}$ & $\begin{array}{l}\text { An additional } \\
\text { unnecessary cost. }\end{array}$ & $\begin{array}{l}\text { Improves firm } \\
\text { performance by } \\
\text { reducing type one and } \\
\text { type two agency costs. }\end{array}$ & $\begin{array}{l}\text { Improves firm performance by } \\
\text { providing service and advice } \\
\text { that cannot be provided by the } \\
\text { virtue of family or affiliates } \\
\text { appointment. }\end{array}$ \\
\hline
\end{tabular}


Table 2. Distribution of companies according to sector

\begin{tabular}{|l|r|r|r|r|}
\hline \multicolumn{1}{|c|}{ Sector } & Frequency & \multicolumn{1}{c|}{ Percent } & $\begin{array}{c}\text { Valid } \\
\text { Percent }\end{array}$ & $\begin{array}{c}\text { Cumulative } \\
\text { Percent }\end{array}$ \\
\hline Food and Beverages & 20.0 & 27.0 & 27.0 & 27.0 \\
\hline Banking. Finance and Insurance & 2.0 & 2.7 & 2.7 & 29.7 \\
\hline Manufacturing & 9.0 & 12.2 & 12.2 & 41.9 \\
\hline Tourism & 11.0 & 14.9 & 14.9 & 56.8 \\
\hline Telecommunications & 6.0 & 8.1 & 8.1 & 64.9 \\
\hline Other & 3.0 & 4.1 & 4.1 & 68.9 \\
\hline Real Estate & 6.0 & 8.1 & 8.1 & 77.0 \\
\hline Media & 3.0 & 4.1 & 4.1 & 81.1 \\
\hline Retail & 14.0 & 18.9 & 18.9 & 100.0 \\
\hline Total & 74.0 & 100.0 & 100.0 & \\
\hline
\end{tabular}

Table 3. Distribution of respondents according to educational level.

\begin{tabular}{|l|r|r|r|r|}
\hline Highest level of education & \multicolumn{1}{|c|}{ Frequency } & \multicolumn{1}{c|}{ Percent } & $\begin{array}{c}\text { Valid } \\
\text { Percent }\end{array}$ & \multicolumn{2}{c|}{$\begin{array}{c}\text { Cumulative } \\
\text { Percent }\end{array}$} \\
\hline High School & 4.0 & 5.4 & 5.4 & 5.4 \\
\hline Bachelor's Degree & 46.0 & 62.2 & 62.2 & 67.6 \\
\hline Master's Degree & 24.0 & 32.4 & 32.4 & 100.0 \\
\hline Total & 74.0 & 100.0 & 100.0 & \\
\hline
\end{tabular}


Table 4. Variable definition and calibration values

\begin{tabular}{|c|c|c|c|c|}
\hline \multirow[b]{2}{*}{ Condition } & \multirow[b]{2}{*}{ Description } & \multicolumn{3}{|c|}{ Membership threshold values ${ }^{\mathrm{a}}$} \\
\hline & & $\begin{array}{c}\text { Full non- } \\
\text { members } \\
\text { hip } \\
(0.05)\end{array}$ & $\begin{array}{l}\text { Crossove } \\
\text { r point } \\
(0.5)\end{array}$ & $\begin{array}{l}\text { Full } \\
\text { membership } \\
(0.95)\end{array}$ \\
\hline $\begin{array}{l}\text { Firm } \\
\text { performance }\end{array}$ & $\begin{array}{l}\text { The sum of individual } \\
\text { perceptual performance } \\
\text { measures }\end{array}$ & 13.75 & 30.00 & 36.00 \\
\hline $\begin{array}{l}\text { Family } \\
\text { ownership }^{c}\end{array}$ & $\begin{array}{l}\text { Percentage of the business } \\
\text { equity held by the same family } \\
\text { group }(100 \%=1 ;<100 \%=0)\end{array}$ & 0 & & 1 \\
\hline $\begin{array}{l}\text { Independent } \\
\text { directors }^{\mathrm{c}}\end{array}$ & $\begin{array}{l}\text { Indicates the presence of } \\
\text { independent directors on the } \\
\text { board (yes }=1 ; \text { no }=0 \text { ) }\end{array}$ & 0 & & 1 \\
\hline Founder $\mathrm{CEO}^{\mathrm{c}}$ & $\begin{array}{l}\text { Captures whether the founder } \\
\text { is still involved as CEO of the } \\
\text { company (yes }=1 ; \text { no }=0 \text { ) }\end{array}$ & 0 & & 1 \\
\hline $\begin{array}{l}\text { Family } \\
\text { management }\end{array}$ & $\begin{array}{l}\text { Percentage of family members } \\
\text { in the management team }\end{array}$ & $13.49 \%$ & $50.00 \%$ & $100.00 \%$ \\
\hline Board size $^{\mathrm{b}}$ & $\begin{array}{l}\text { Number of members in the } \\
\text { board of the firm }\end{array}$ & 3.00 & 4 & 9.00 \\
\hline
\end{tabular}

${ }^{a}$ Observations falling in the percentile-95 are considered to represent full set membership.

Percentile-1 5 is the threshold value for indicating full non-membership. The crossover point is defined by the median.

${ }^{\mathrm{b}}$ Observations falling in the percentile-95 are considered to represent full set membership. Percentile-02 is the threshold value for indicating full non-membership. The crossover point is defined by the mean.

${ }^{\mathrm{c}}$ Variables expressed in crisp-set terms 
Table 5. Analysis of necessary conditions

\begin{tabular}{|l|c|c|}
\hline Conditions tested $^{*}$ & Consistency & Coverage \\
\hline family ownership & 0.5778 & 0.5161 \\
\hline$\sim$ family ownership & 0.4222 & 0.4950 \\
\hline independent directors & 0.5338 & 0.5891 \\
\hline$\sim$ independent directors & 0.4662 & 0.4373 \\
\hline CEO founder & 0.5163 & 0.4967 \\
\hline$\sim$ CEO founder & 0.4837 & 0.5186 \\
\hline family management team & 0.6093 & 0.6906 \\
\hline$\sim$ family management team & 0.6778 & 0.6218 \\
\hline board size & 0.4784 & 0.7014 \\
\hline$\sim$ board size & 0.7201 & 0.5581 \\
\hline
\end{tabular}

The symbol ( ) represents the negation of the characteristic.

Table 6. Sufficient configurations of antecedent conditions for performance

\begin{tabular}{|c|c|c|c|c|c|c|c|c|}
\hline \multirow{2}{*}{$\begin{array}{l}\text { Configuration } \\
\text { no. }\end{array}$} & \multicolumn{5}{|c|}{ Antecedent conditions } & \multicolumn{2}{|c|}{ Coverage } & \multirow[t]{2}{*}{ Consistency } \\
\hline & 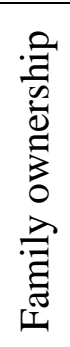 & 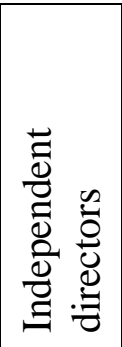 & 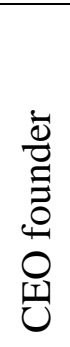 & 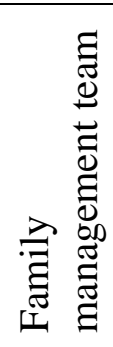 & 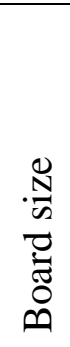 & Raw & Unique & \\
\hline 1 & 0 & - & 0 & 0 & & 0.2188 & 0.0760 & 0.8202 \\
\hline 2 & 0 & - & & 0 & - & 0.2343 & 0.0914 & 0.8509 \\
\hline 3 & $\bullet$ & $\bullet$ & - & & 0 & 0.0445 & 0.0445 & 0.7076 \\
\hline 4 & - & 0 & - & & - & 0.0560 & 0.0053 & 0.7955 \\
\hline 5 & 0 & 0 & & - & $\bullet$ & 0.1154 & 0.0394 & 0.9292 \\
\hline 6 & - & 0 & 0 & 0 & 0 & 0.0784 & 0.0530 & 0.8122 \\
\hline
\end{tabular}

Frequency threshold $=1$; consistency threshold $=0.8122$. 


\section{Appendix A}

Survey questions used during phone interviews

\begin{tabular}{|c|c|c|}
\hline Dimension & Question & Answers \\
\hline Family ownership & $\begin{array}{l}\text { What is the highest } \\
\text { percentage of business } \\
\text { equity held by the same } \\
\text { extended family in the year } \\
\text { of } 2015 \text { (total family } \\
\text { ownership of the business)? }\end{array}$ & $\begin{array}{ll} & 100 \% \\
O & \text { Less Than } 100 \% . \text { Please specify. }\end{array}$ \\
\hline $\begin{array}{l}\text { Family involvement } \\
\text { in management }\end{array}$ & $\begin{array}{l}\text { Please provide the following } \\
\text { information about the top } \\
\text { management team } \\
\text { (executive team) of your } \\
\text { family business: }\end{array}$ & $\begin{array}{l}\text { Number of total positions in the } \\
\text { management team } \\
\text { Number of family members in the } \\
\text { management team }\end{array}$ \\
\hline Founder CEO & $\begin{array}{l}\text { Does the founder occupy the } \\
\text { position of a CEO? }\end{array}$ & $\begin{array}{ll}\text { Y } & \text { Yes } \\
\text { O } & \text { No }\end{array}$ \\
\hline Board characteristics & $\begin{array}{l}\text { Please indicate the } \\
\text { following information about } \\
\text { your board of directors: }\end{array}$ & $\begin{array}{l}\text { Total number of seats } \\
\text { Number of seats occupied by } \\
\text { family members } \\
\text { Number of seats occupied by } \\
\text { affiliates (people that had previous } \\
\text { relationships with the family } \\
\text { and/or the business: lawyers, } \\
\text { consultants, investment bankers, } \\
\text { financiers) } \\
\text { Number of seats occupied by } \\
\text { independent directors (people that } \\
\text { had no prior relationship with the } \\
\text { family or the business prior to their } \\
\text { directorship) }\end{array}$ \\
\hline
\end{tabular}




\section{Appendix B}

Table 7. Robustness check by changing the frequency of cases (3) and consistency threshold $(0.75)$

\begin{tabular}{|c|c|c|c|c|c|c|c|c|}
\hline \multirow{2}{*}{$\begin{array}{l}\text { Configuration } \\
\text { no. }\end{array}$} & \multicolumn{5}{|c|}{ Antecedent conditions } & \multicolumn{2}{|c|}{ Coverage } & \multirow{2}{*}{ Consistency } \\
\hline & 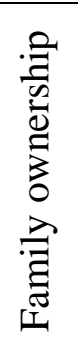 & 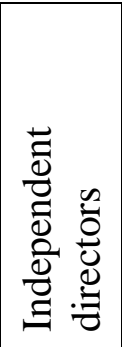 & 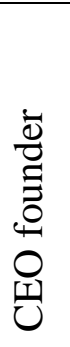 & 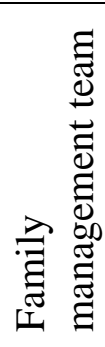 & 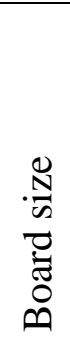 & Raw & Unique & \\
\hline 1 & 0 & - & 0 & 0 & & 0.2188 & 0.0759 & 0.8201 \\
\hline 2 & 0 & - & & 0 & - & 0.2343 & 0.0914 & 0.8509 \\
\hline 3 & - & 0 & 0 & O & 0 & 0.0783 & 0.0530 & 0.8121 \\
\hline 4 & - & 0 & - & & - & 0.0560 & 0.0053 & 0.7955 \\
\hline 5 & - & 0 & - & - & 0 & 0.2476 & 0.2476 & 0.7813 \\
\hline
\end{tabular}

Frequency threshold $=3$; consistency threshold $=0.7813$.

Table 8. Robustness check for older companies (>35 years)

\begin{tabular}{|c|c|c|c|c|c|c|c|c|}
\hline \multirow{2}{*}{$\begin{array}{l}\text { Configuration } \\
\text { no. }\end{array}$} & \multicolumn{5}{|c|}{ Antecedent conditions } & \multicolumn{2}{|c|}{ Coverage } & \multirow[t]{2}{*}{ Consistency } \\
\hline & 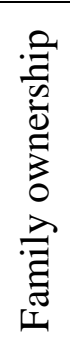 & 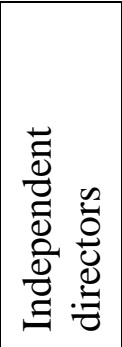 & 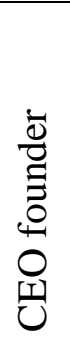 & 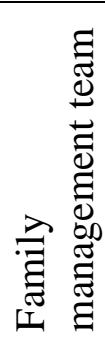 & 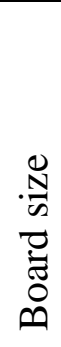 & Raw & Unique & \\
\hline 1 & 0 & - & 0 & 0 & & 0.3053 & 0.3053 & 0.8530 \\
\hline 2 & - & 0 & 0 & - & - & 0.1271 & 0.1271 & 0.9613 \\
\hline 3 & - & 0 & - & 0 & - & 0.0387 & 0.0387 & 0.9810 \\
\hline
\end{tabular}

Frequency threshold $=1$; consistency threshold $=0.8417$. 
Table 9. Robustness check for younger companies ( $\leq 35$ years)

\begin{tabular}{|c|c|c|c|c|c|c|c|c|}
\hline \multirow{2}{*}{$\begin{array}{l}\text { Configuration } \\
\text { no. }\end{array}$} & \multicolumn{5}{|c|}{ Antecedent conditions } & \multicolumn{2}{|c|}{ Coverage } & \multirow[t]{2}{*}{ Consistency } \\
\hline & 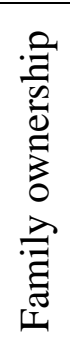 & 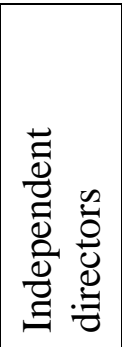 & 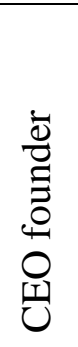 & 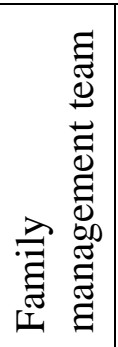 & 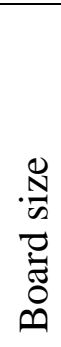 & Raw & Unique & \\
\hline 1 & 0 & - & & 0 & - & 0.2312 & 0.2312 & 0.8555 \\
\hline 2 & - & - & - & & 0 & 0.0700 & 0.0700 & 0.7076 \\
\hline 3 & - & 0 & & - & - & 0.0872 & 0.0872 & 0.8888 \\
\hline 4 & - & 0 & 0 & 0 & 0 & 0.0335 & 0.0205 & 1.000 \\
\hline 5 & - & 0 & - & - & & 0.3705 & 0.3122 & 0.7605 \\
\hline
\end{tabular}

Frequency threshold $=1$; consistency threshold $=0.8071$.

Table 10. Robustness check by replacing independent directors with affiliates

\begin{tabular}{|c|c|c|c|c|c|c|c|c|}
\hline \multirow{2}{*}{$\begin{array}{l}\text { Configuration } \\
\text { no. }\end{array}$} & \multicolumn{5}{|c|}{ Antecedent conditions } & \multicolumn{2}{|c|}{ Coverage } & \multirow[t]{2}{*}{ Consistency } \\
\hline & 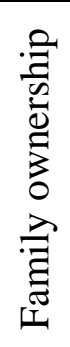 & 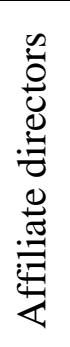 & 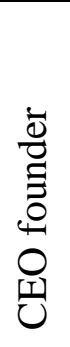 & 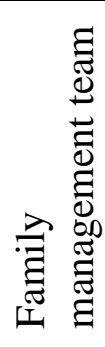 & 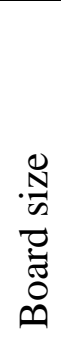 & Raw & Unique & \\
\hline 1 & $\bullet$ & 0 & & $\bullet$ & - & 0.1325 & 0.0866 & 0.8283 \\
\hline 2 & - & 0 & - & - & & 0.1924 & 0.1465 & 0.7747 \\
\hline 3 & 0 & - & 0 & 0 & - & 0.0725 & 0.0725 & 0.8143 \\
\hline
\end{tabular}

Frequency threshold $=2$; consistency threshold $=0.8085$. 